\title{
Pháp luật về môi giới bất động sản ở Việt Nam
}

Nguyễn Xuân Thắng

Hà Nội, 31-5-2018 
Lời cam đoan i

Lời cảm ơn .ii

Danh mục các ký hiệu, chữ viết tắt. $\mathrm{V}$

PHẦN MỞ ĐẦU 1

1. Tính cấp thiết của đề tài. .1

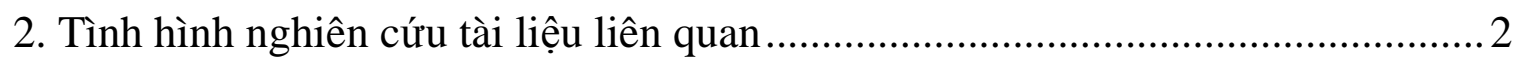

3. Mục tiêu nghiên cứu .................................................................................. 4

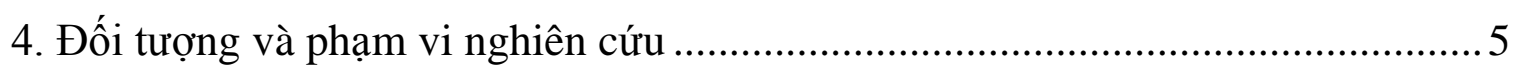

5. Phương pháp nghiên cứu .........................................................................

6. Kết cấu dự kiến của luận văn............................................................................5

CHƯƠNG 1: KHÁI QUÁT CHUNG VÀ CÁC QUY ĐỊNH PHÁP LUẬT VỀ MÔI GIỚI BÂT ĐộNG SẢN .. .6

1.1. KHÁI NIỆM, ĐẶC TRƯNG VÀ VAI TRÒ CỦA MÔI GIỚI BÂT ĐộNG

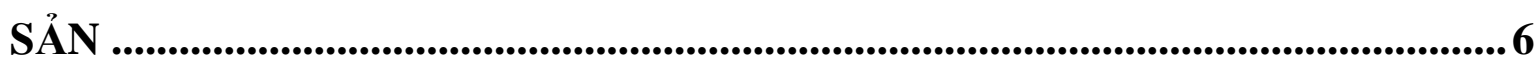

1.1.1. Khái niệm về bất động sản ........................................................................... 6

1.1.2. Khái niệm về môi giới bất động sản............................................................. 8

1.1.3. Đặc trưng của môi giới bất động sản............................................................. 9

1.1.4. Vai trò của môi giới bất động sản ............................................................... 11

1.2. CÁC QUY ĐỊNH PHÁP LUẬT CỦA VIỆT NAM ĐỐI VỚI HOẠT ĐộNG MÔI GIỚI BÁT ĐộNG SẢN ..................................................................................15

1.2.1. Sự cần thiết của pháp luật về môi giới bất động sản .................................... 15

1.2.2. Điều kiện của tổ chức, cá nhân kinh doanh dịch vụ môi giới bất động sản

1.2.3. Thù lao môi giới và hoa hồng môi giới bất động sản.................................. 21

1.2.4. Quyền và nghĩa vụ của các bên trong môi giới bất động sản....................... 21

1.2.5. Tác động của các quy định pháp luật đến hoạt động môi giới bất động sản.

1.3. QUY ĐỊNH PHÁP LUẬT CỦA MộT SỐ QUỐC GIA VỀ HOẠT ĐộNG MÔI GIỚI BẤT ĐộNG SẢN ....................................................................................28

1.3.1. Nghề môi giới bất động sản tại Thụy Điển ................................................ 28 
1.3.2. Nghề môi giới bất động sản tại Mỹ

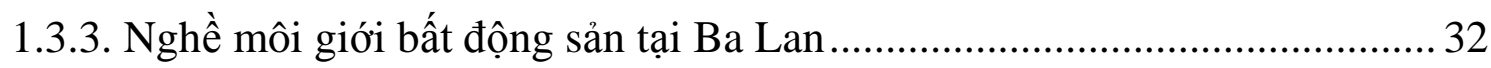

CHƯƠNG 2: THỰC TRẠNG VÀ HƯỚNG HOÀN THIỆN HOẠT ĐỘNG MÔI GIỚI BẤT ĐộNG SẢN THEO PHÁP LUẬT VIỆT NAM ........................................35

2.1. THỰC TRẠNG HOẠT ĐộNG MÔI GIỚI BÂT ĐộNG SẢN THEO PHÁP

LUẬT VIỆT NAM. 35

2.1.1. Hoạt động của tổ chức, cá nhân kinh doanh dịch vụ môi giới bất động sản .. 35

2.1.2. Quản lý Nhà nước đối với hoạt động môi giới bất động sản 42

2.2. NGUYÊN NHÂN CỦA THỰC TRẠNG MÔI GIỚI BẤT ĐộNG SẢN Ở VIẸT NAM HIỆN NAY . .44

2.3. HƯỚNG HOÀN THIỆN PHÁP LUẬT VIỆT NAM VỂ HOẠT ĐỘNG MÔI GIỚI BÂT ĐộNG SẢN ..........................................................................................46

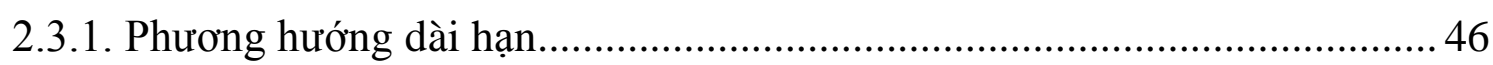

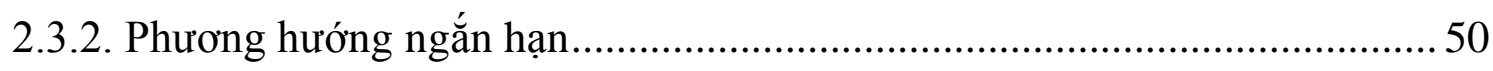

PHẦ KẾT LUẬN..................................................................................................55

DANH MỤC TÀI LIỆU THAM KHẢO........................................................................56 


\section{DANH MỤC CÁC KÝ HIỆU, CHŨ̉ VIẾT TẮT}

BĐS: Bất động sản

TT-BXD: Thông tư Bộ xây dựng

NĐ-CP: Nghị định của Chính phủ 


\section{PHÀ̀N MỞ ĐẦU}

\section{TÍNH CẤP THIẾT CỦA ĐỀ TÀI}

Theo quy định của Luật đất đai và Luật nhà ở, công dân có quyền sử dụng đối với đất đai, quyền sở hữu đối với nhà ở và tài sản khác gắn liền với đất. Đồng thời, chủ sử dụng, chủ sở hữu có quyền thực hiện các loại hình giao dịch có liên quan như mua bán, tặng cho, cho thuê, thừa kế, thế chấp... đối với quyền sử dụng đất và nhà ở ${ }^{1}$. Đây chính là cơ sở, tiền đề cho việc hình thành và phát triển thị trường bất động sản ở Việt Nam nói chung và hoạt động môi giới bất động sản nói riêng.

Hoạt động kinh doanh bất động sản luôn thu hút được sự tham gia của nhiều thành phần trong xã hội hiện đại bởi sự hấp dẫn về lợi nhuận mà nó mang lại. Tuy nhiên, cũng như những loại hình kinh doanh khác, hình thức kinh doanh này cũng tiềm ẩn nhiều rủi ro theo quy luật của thị trường (lợi nhuận cao thì rủi ro cao). Để góp phần hạn chế phần rủi ro đó cũng như giữ vai trò kết nối giữa nhà cung cấp và khách hàng, thị trường đã xuất hiện thành phần thứ ba là nhà môi giới bất động sản. Đây là thành phần giúp khách hàng kiểm tra tính hợp pháp của hàng hóa mà nhà cung cấp bán, đồng thời tạo điều kiện cho người mua và người bán có thể tiếp xúc được với nhau, hạn chế được rủi ro trong giao dịch.

Từ tầm quan trọng như vậy, hoạt động môi giới bất động sản luôn nhận được sự quan tâm của Nhà nước thông qua việc ghi nhận cụ thể trong các văn bản pháp luật, đầu tiên phải kể đến là Luật kinh doanh bất động sản 2006 và các văn bản hướng dẫn thi hành. Sau quá trình triển khai, nhằm khắc phục những hạn chế của Luật kinh doanh bất động sản 2006, Quốc hội đã ban hành Luật kinh doanh bất động sản 2014. Về cơ bản, các nội dung của việc môi giới như điều kiện của tổ chức, cá nhân kinh doanh dịch vụ môi giới bất động sản, nội dung môi giới bất động sản, quyền và nghĩa vụ của doanh nghiệp, cá nhân kinh doanh dịch vụ môi giới bất động sản ... đã được Luật kinh doanh bất động sản 2014 quy định một cách tương đối đầy đủ.

Tuy nhiên, qua quá trình triển khai thi hành, vẫn còn tồn tại một số hạn chế trong lĩnh vực môi giới bất động sản cần tiếp tục khắc phục. Chẳng hạn, một số tổ chức mối giới bất động sản được hình thành và hoạt động mà không hề có bằng cấp, chứng chỉ gì. Đây là một thực trạng gây rất nhiều hệ lụy không tố đến sự phát triển của thị trường bất

\footnotetext{
${ }^{1}$ Luật Đất đai 2013 (Luật số 45/2013/QH13) ngày 29/11/2013, Điều 167. Luật nhà ở 2014 (Luật số: 65/2014/QH13) ngày 25/11/2014, Điều 117.
} 
động sản nói chung. Bởi, thị trường bất động sản là một trong những thị trường có nhiều biến động, đòi hỏi các đơn vị môi giới bất động sản phải luôn biết cập nhật thông tin mới, những biến động có lợi hay rủi ro có thể gặp phải để từ đó ngày càng trở nên chuyên nghiệp và biết ứng phó với những tình huống bất ngờ xảy ra, đặc biệt là phải có đạo đức nghề nghiệp và chịu dưới sự quản lí của nhà nước. Mặt khác, chất lượng nghiệp vụ và đặc biệt là tính chuyên môn của các đơn vị môi giới bất động sản hiện nay của Việt Nam vẫn chưa đủ đáp ứng, xứng tầm khu vực và thế giới. Điều này khiến cho những nhà môi giới trong nước không thể cạnh tranh với những nhà môi giới nước ngoài trong xu thế phát triển thị trường. Từ đó nhu cầu đặt ra đối với ngành môi giới bất động sản là phải hoàn thiện và nâng cao chất lượng cho nghề.

Xuất phát từ những vấn đề trên, tác giả mạnh dạn lựa chọn đề tài "Pháp luật về môi giới bất động sản ở Việt Nam" làm luận văn thạc sỹ của mình.

\section{TÌNH HÌNH NGHIÊN CÚ'U TÀI LIỆU LIÊN QUAN}

Qua quá trình tìm hiểu, tác giả nhận thấy có một số công trình liên quan đến đề tài luận văn như:

- Thứ nhất, Phạm Minh Chính và Vương Quân Hoàng (2009), trong quyển "Kinh tế Việt Nam - Thăng trầm và Đột phá" đã miêu tả thị trường bất động sản của Việt Nam và các nước trên thế giới qua các thời kỳ lịch sử. Hai tác giả cũng nêu lên “những chủ thể tham gia vào thị trường bất động sản ngày càng tăng bên cạnh các thành viên truyền thống của thị trường (cá nhân, hộ gia đình) thì còn có các doanh nghiệp Nhà nước. Để đáp ứng nhu cầu của thị trường bất động sản, nhiều loại hình tổ chức cũng đã ra đời và tăng nhanh về quy mô trong đó có các tổ chức dịch vụ môi giới về nhà đất."2

- Thứ hai, bài viết "Kinh nghiệm thực tiễn dịch vụ môi giới bất động sản: "Kinh nghiệm quốc tế thực tiễn và định hướng phát triển ở Việt Nam” của tác giả Lưu Đức Khải và Hà Huy Ngọc năm 2009 đã nêu khái quát tình hình môi giới bất động sản tại Việt Nam và kinh nghiệm về phát triển dịch vụ môi giới bất động sản ở một số nước trên thế giới như Mỹ, các nước Châu Âu hay đào tạo giấy phép môi giới bất động sản ở Singapore, từ đó đề ra cơ hội và định hướng phát triển nghề môi giới bất động sản ở Việt Nam.

- Thứ ba, tác giả Đinh Văn Ân (2011) trong xuất bản về Chính sách phát triển thị trường bất động sản ở Việt Nam cho thấy “các nhà môi giới là một trong những thành

\footnotetext{
${ }^{2}$ Phạm Minh Chính, Vương Quân Hoàng (2009), Kinh tế Việt Nam - Thăng trầm và Đột phá, Nxb. Chính trị Quốc gia, Hà Nội.
} 
tố của thị trường bất động sản, là các tổ chức trung gian được thành lập dựa trên nhu cầu của thị trường, do sự phát triển của thị trường bất động sản tạo ra nhu cầu rất lớn về nhân lực trong xã hội”3... Nhu cầu này thúc đẩy phát triển các trường đào tạo nghề, các tổ chức được phép đào tạo và cấp chứng chỉ hành nghề môi giới bất động sản. Các tổ chức môi giới kinh doanh bất động sản có thể được thành lập tự do hoặc môi giới theo tổ chức được pháp luật thừa nhận. Đối với nghề môi giới tự do, khi cấp giấy hành nghề, pháp luật không đòi hỏi họ phải có trình độ chuyên môn, nhưng để trở thành hội viên của Hiệp hội môi giới thì trình độ chuyên môn là điều kiện bắt buộc, đây cũng là một trong những hạn chế của pháp luật hiện hành đối với nghề môi giới bất động sản ở thời điểm đó.

- Thứ tư, Nguyễn Quang Tuyến và Nguyễn Thị Nga (2011) đã phân tích và đưa ra rằng những tồn tại, hạn chế của pháp luật về môi giới bất động sản được biết đến bắt nguồn từ các nguyên nhân chủ yếu như: "hệ thống pháp luật về kinh doanh bất động sản nói chung và các quy định về môi giới bất động sản nói riêng đang trong quá trình xây dựng và hoàn thiện nên không tránh khỏi sự thiếu đồng bộ, hoàn chỉnh. Vấn đề này cần

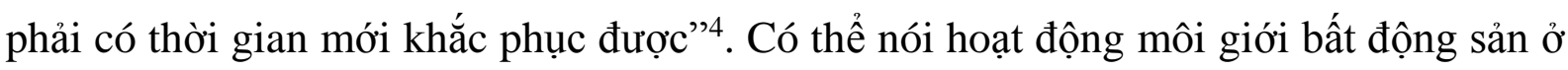
Việt Nam còn khá non trẻ so với các quốc gia khác trên thế giới, đây cũng là một trở ngại cho quá trình thực thi pháp luật về môi giới bất động sản bởi hệ thống cơ quan quản lí chuyên trách về thị trường bất động sản đang trong quá trình củng cố và hoàn thiện, đội ngũ cán bộ, công chức làm công tác quản lí nhà nước về thị trường bất động sản có năng lực, trình độ chuyên môn không đồng đều và hạn chế. Điều này làm giảm hiệu quả công tác thực thi pháp luật về môi giới bất động sản, trình độ dân trí và tốc độ phát triển kinh tế không đồng đều giữa các vùng, khu vực trong cả nước cũng là nguyên nhân gây trở ngại cho sự phát triển của hoạt động môi giới bất động sản.

- Thứ năm, bài viết "Tạo dựng đẳng cấp thương hiệu môi giới bất động sản và một số giải pháp hoàn thiện pháp luật về môi giới bất động sản ở Việt Nam” trên tạp chí xây dựng số 20 năm 2014 của tác giả Doãn Hồng Nhung. Bài viết đã đưa ra quan điểm cho rằng "môi giới bất động sản khoát lên mình sứ mệnh quan trọng tạo chất xúc tác đưa các giao dịch tới thành công đồng thời thúc đẩy sự phát triển của trị trường bất động

\footnotetext{
${ }^{3}$ Đinh Văn Ân (2011), Chính sách phát triển thị truờng bất động sản ở Việt Nam, Nxb Chính trị Quốc Gia, Hà Nội.

${ }^{4}$ Nguyễn Quang Tuyến, Nguyễn Thị Nga (2011), "Pháp luật môi giới BĐS Việt Nam và kiến nghị hoàn thiện", Tạp chí luật học, (6), tr. 47-52.
} 
sản”. Đồng thời, tác giả cũng nêu những biện pháp để tạo dựng đẳng cấp thương hiệu môi giới bất động sản và một số giải pháp hoàn thiện pháp luật về môi giới bất động sản ở Việt Nam.

- Bên cạnh các tài liệu là sách, báo, tạp chí, văn bản pháp luật nhà nước, thì tác giả thực hiện đề tài cũng nghiên cứu các tài liệu khác như luận văn, luận án, đề tài nghiên cứu khoa học cấp Bộ,... có trình bày các vấn đề có liên quan đến môi giới bất động sản cụ thể như luận văn thạc sĩ của Nguyễn Ngọc Tú năm 2007 thực hiện về "Thống nhất pháp luật về đăng ký bất động sản " hay "Đăng ký bất động sản - thực tiễn và phương hướng hoàn thiện", Luận văn thạc sĩ luật học của Phạm Thị Kim Hiền được viết vào năm 2001. Năm 2009 Nguyễn Thị Thu Hằng đã tiến hành đề tài về "Pháp luật đăng ký bất động sản của Việt Nam và Nhật Bản - Một số kiến nghị hoàn thiện pháp luật Việt Nam" cho Luận văn thạc sĩ luật học của mình. Đặc biệt là đề tài nghiên cứu khoa học cấp Bộ của Bộ Tư pháp năm 2004 về "Cơ sở lý luận và thực tiễn của chế độ đăng ký bất động sản tại Việt Nam".

Nhìn chung, các vấn đề về dịch vụ môi giới bất động sản đã được nêu ra và phân tích trong một số công trình có liên quan. Đây là những tư liệu quý giá để tác giả thực hiện đề tài của mình. Tuy nhiên, cho đến thời điểm hiện tại vẫn chưa có một công trình nào nghiên cứu một cách chuyên sâu và toàn diện các vấn đề pháp lý và thực trạng thi hành đối với vấn đề này. Chính vì vậy, luận văn của tác giả sẽ là một công trình mới giúp hoàn thiện các vấn đề về dịch vụ môi giới bất động sản tại Việt Nam.

\section{MỤC TIÊU NGHIÊN CÚU}

\subsection{Mục tiêu chung}

Nghiên cứu các quy định có liên quan đến hoạt động môi giới bất động sản. Phân tích những bất cập vướng mắc đã và đang gặp phải từ đó đề xuất các giải pháp, kiến nghị góp phần hoàn thiện Luật kinh doanh bất động sản về hoạt động môi giới bất động sản.

\subsection{Mục tiêu cụ thể}

+ Phân tích những quy định của Luật kinh doanh bất động sản và các quy phạm pháp luật Việt Nam liên quan đến môi giới bất động sản.

+ Tìm hiểu thực trạng thực hiện những quy định của pháp luật về hoạt động môi giới bất động sản, phân tích những bất cập, khó khăn vướng mắc trong quá trình thực hiện. 
+ Đề xuất giải pháp và hướng hoàn thiện pháp luật trong tương lai về hoạt động môi giới bất động sản.

\section{4. ĐỐI TƯợNG VÀ PHẠM VI NGHIÊN CÚU Đối tượng nghiên cứu}

Đề tài nghiên cứu các quy định của pháp luật trong lĩnh vực kinh doanh bất động sản và đặc biệt chú trọng đến các quy định liên quan đến môi giới bất động sản.

\section{Phạm vi nghiên cứu}

- Nội dung nghiên cứu

○ Thực tiễn hoạt động môi giới bất động sản.

○ Pháp luật về hoạt động môi giới bất động sản.

+ Những thay đổi trong các quy phạm pháp luật về bất động sản.

+ Thực tiễn áp dụng pháp luật trong hoạt động môi giới bất động sản.

+ Những khó khăn trong quá trình thi hành pháp luật.

+ Xác định nguyên nhân dẫn đến những khó khăn trong thi hành pháp luật.

+ Nghiên cứu hướng khắc phục khó khăn nhằm hoàn thiện pháp luật.

- Không gian nghiên cứu: Tác giả sẽ đi vào nghiên cứu các quy định pháp luật của Việt Nam về môi giới bất động sản

- Thời gian nghiên cứu: Đề tài thực hiện nghiên cứu kể từ khi Luật kinh doanh bất động sản 2006 được áp dụng cho đến nay.

\section{PHƯƠNG PHÁP NGHIÊN CÚUU}

- Phương pháp phân tích, tổng hợp: tác giả tổng hợp những quy định nổi bật của pháp luật Việt Nam liên quan đến vấn đề môi giới bất động sản, đồng thời đưa ra những phân tích đánh giá, nhận xét những điểm hợp lý, hạn chế của những quy định này trong bối cảnh của Việt Nam qua các thời kỳ từ năm 2006 cho đến nay.

- Phương pháp so sánh: so sánh pháp luật Việt Nam về môi giới bất động sản với một số nước có điểm tương đồng về mức độ phát triển, cũng như các quy định đổi mới qua các thời kỳ để thấy được sự biến đổi của pháp luật Việt Nam về vấn đề môi giới bất động sản qua các thời kỳ.

\section{KỄT CẤU DỰ KIẾN CỦA LUẬn VĂN}

Chương 1. Khái quát chung và các quy định pháp luật về môi giới bất động sản

Chương 2. Thực trạng và hướng hoàn thiện hoạt động môi giới bất động sản theo pháp luật Việt Nam 


\section{CHƯƠNG 1: KHÁI QUÁT CHUNG VÀ CÁC QUY ĐỊNH PHÁP LUẬT VỀ MÔI GIỚI BẤT ĐộNG SẢN}

\subsection{KHÁI NIỆM, ĐẶC TRƯNG VÀ VAI TRÒ CỦA MÔI GIỚI BẤT ĐộNG SẢN}

\subsubsection{Khái niệm về bất động sản}

Pháp luật Việt Nam hiện nay chưa có một quy định giải thích khái niệm BĐS là gì mà chỉ tiếp cận dưới góc độ là một bộ phận của tài sản ${ }^{5}$ và theo phương thức liệt kê. Cụ thể, theo Bộ luật dân sự 2015 (BLDS 2015), BĐS bao gồm: Đất đai; Nhà, công trình xây dựng gắn liền với đất đai; Tài sản khác gắn liền với đất đai, nhà, công trình xây dựng; Tài sản khác theo quy định của pháp luật ${ }^{6}$.

Nghiên cứu so sánh với pháp luật thế giới, có thể thấy BLDS 2015 tương đồng với hầu hết các quốc gia khác tron việc phân loại tài sản thành "BĐS" và "động sản". Việc phân loại này xuất phát từ các quy định trong luật cổ của La Mã. Theo đó, BĐS không chỉ là đất đai, của cải trong lòng đất mà còn là tất cả những gì được tạo ra do sức lao động của con người gắn liền với đất đai như các công trình xây dựng, mùa màng, cây trồng,... và tất cả những gì liên quan đến đất đai hay gắn liền với đất đai theo không gian 3 chiều (chiều cao, chiều sâu, chiều rộng) để tạo thành một dạng vật chất có cấu trúc và công năng được xác định. Để ngắn gọn và dễ hiểu hơn, hầu hết các nước trên thế giới đều coi BĐS là đất đai và những tài sản gắn liền với đất đai, không tách rời với đất đai, được xác định bởi vị trí địa lí của đất ${ }^{7}$. Cụ thể, Điều 520 Bộ luật Dân sự Pháp quy định “mùa màng chưa gặt, trái cây chưa rời khỏi cây là $\mathrm{BĐS}$, nếu rời khỏi cây thì sẽ gọi là động sản”. Tương tự, quy định này cũng được thể hiện ở Luật Dân sự Nhật Bản. Trong khi đó, Điều 100 Luật Dân sự Thái Lan quy định: "BĐS là đất đai và những vật gắn liền với đất đai, bao gồm cả những quyền gắn với việc sở hữu đất đai”. Luật Dân sự Đức đưa ra khái niệm $\mathrm{BĐS} \mathrm{bao} \mathrm{gồm} \mathrm{đất} \mathrm{đai} \mathrm{và} \mathrm{các} \mathrm{tài} \mathrm{sản} \mathrm{gắn} \mathrm{với} \mathrm{đất.} \mathrm{Luật} \mathrm{Dân} \mathrm{sự} \mathrm{Nga}$ năm 1994 quy định về BĐS đã có những điểm khác biệt đáng chú ý so với các Luật Dân sự truyền thống. Điều 130 của Luật này một mặt, liệt kê tương tự theo cách của các Luật Dân sự truyền thống; mặt khác, đưa ra khái niệm chung về BĐS là "những đối tượng

\footnotetext{
${ }^{5}$ Bộ Luật Dân sự 2015 (Luật số 33/2015/QH11) ngày 14/6/2015, Khoản 2 Điều 105: "Tài sản bao gồm bất động sản và động sản. Bất động sản và động sản có thể là tài sản hiện có và tài sản hình thành trong tuơng lai”"

${ }^{6}$ Bộ Luật Dân sự 2015 (Luật số 33/2015/QH11) ngày 14/6/2015, Khoản 1 Điều 107.

${ }^{7}$ Thông tin pháp luật dân sự, "Khái niệm, đặc điểm, phân loại bất động sản", https://thongtinphapluatdansu. edu.vn/2008/01/01/3521/, ngày truy cập: 10/11/2017
} 
mà dịch chuyển sẽ làm tổn hại đến giá trị của chúng”. Bên cạnh đó, Luật này còn liệt kê những vật không liên quan gì đến đất đai như "tàu biển, máy bay, phương tiện vũ trụ..." cũng là các BĐS.

Như vậy, khái niệm BĐS rất rộng, đa dạng và cần được quy định cụ thể bằng pháp luật của mỗi nước và có những tài sản có quốc gia cho là $\mathrm{BĐS,} \mathrm{trong} \mathrm{khi} \mathrm{quốc} \mathrm{gia}$ khác lại liệt kê vào danh mục BĐS. Qua kinh nghiệm của một số quốc gia trên thế giới và kết quả nghiên cứu của nước ta, $\mathrm{BĐS}$ có thể được chia làm 3 nhóm: $\mathrm{BĐS} \mathrm{có} \mathrm{đầu} \mathrm{tư}$ xây dựng, BĐS không đầu tư xây dựng và $\mathrm{BĐS} \mathrm{đặc} \mathrm{biệt.} \mathrm{Việc} \mathrm{phân} \mathrm{chia} \mathrm{BĐS} \mathrm{theo} 3$ loại trên đây là rất cần thiết bảo đảm cho việc xây dựng cơ chế chính sách về phát triển và quản lý thị trường $\mathrm{BĐS}$ phù hợp với điều kiện kinh tế - xã hội của nước ta. Trong đó:

- BĐS có đầu tư xây dựng gồm: $\mathrm{BĐS} \mathrm{nhà} \mathrm{ở,} \mathrm{BĐS} \mathrm{nhà} \mathrm{xưởng} \mathrm{và} \mathrm{công} \mathrm{trình}$ thương mại- dịch vụ, BĐS hạ tầng (hạ tầng kỹ thuật, hạ tầng xã hội), BĐS là trụ sở làm việc v.v.. Trong BĐS có đầu tư xây dựng thì nhóm BĐS nhà đất (bao gồm đất đai và các tài sản gắn liền với đất đai) là nhóm $\mathrm{BĐS}$ cơ bản, chiếm tỷ trọng rất lớn, tính chất phức tạp rất cao và chịu ảnh hưởng của nhiều yếu tố chủ quan và khách quan. Nhóm này có tác động rất lớn đến quá trình công nghiệp hoá, hiện đại hoá đất nước cũng như phát triển đô thị bền vững. Nhưng quan trọng hơn là nhóm BĐS này chiếm tuyệt đại đa số các giao dịch trên thị trường $\mathrm{BĐS}$ ở nước ta cũng như ở các nước trên thế giới.

- BĐS không đầu tư xây dựng: BĐS thuộc loại này chủ yếu là đất nông nghiệp (dưới dạng tư liệu sản xuất) bao gồm các loại đất nông nghiệp, đất rừng, đất nuôi trồng thuỷ sản, đất làm muối, đất hiếm, đất chưa sử dụng v.v..

BĐS đặc biệt là những BĐS như các công trình bảo tồn quốc gia, di sản văn hoá vật thể, nhà thờ họ, đình chùa, miếu mạo, nghĩa trang v.v.. Đặc điểm của loại BĐS này là khả năng tham gia thị trường rất thấp ${ }^{8}$.

BĐS có một số thuộc tính căn bản sau:

- Tính bất động là đặc trưng khác biệt của hàng hóa $\mathrm{BĐS} \mathrm{so} \mathrm{với} \mathrm{các} \mathrm{hàng} \mathrm{hóa}$ khác: đất đai là hàng hóa đặc biệt, dù được đem chuyển nhượng, nhưng không thể chuyển $\mathrm{BĐS}$ đó đến một nơi họ muốn, đến một vị trí khác. Quyền sử dụng đất nằm trong thị trường $\mathrm{BĐS}$, vị trí của đất đai gắn liền với điều kiện sinh thái, kinh tế - xã hội, điều

\footnotetext{
${ }^{8}$ Nguyễn Mạnh Hùng (2016), “Thị trường BĐS Việt Nam thực trạng và giải pháp”, Tạp chí Truờng Đại học Nam Cần Tho:

${ }^{9}$ Đinh Văn Ân (2011), Chính sách phát triển thị truờng bất động sản ở Việt Nam, Nxb Chính trị Quốc Gia, Hà Nội.
} 
đó đã tác động đến phương thức sử dụng đất và giá đất, đó chính là nguyên nhân tại sao giá đất lại khác nhau dù ở vị trí kế cận nhau

- Tính không đồng nhất: trong nền kinh tế thị trường, hàng hóa rất đa dạng và rất phức tạp nên khó có thể tìm được 02 tài sản giống nhau hoàn toàn mà nó chỉ tương đồng về đặc điểm, chính vì vậy mà giá cả của BĐS gắn liền với đặc điểm của mỗi tài sản. Giả sử rằng, hai $\mathrm{BĐS}$ nằm cùng trong một khu vực nhưng giá của chúng còn phụ thuộc vào thời điểm bán như thế nào, người mua có thích hay không, tâm lí của người đi mua lúc đó như thế nào và đặc điểm cụ thể của $\mathrm{BĐS}$ đó nữa, tất cả đều chứng minh cho sự không đồng nhất trong nền kinh tế thị trường hiện nay

- Tính khan hiếm: diện tích đất là có hạn so với sự phát triển dân số, do vậy về lâu dài giá đất có xu hướng ngày càng tăng lên. Diện tích đất đai có chiều hướng giảm có rất nhiều nguyên nhân. Một là, do tốc độ tăng dân số nhanh đặc biệt là vùng nông thôn. Hai là, do tốc độ phát triển kinh tế thị trường theo hướng công nghiệp hóa, hiện đại hóa làm cho diện tích đât nông nghiệp giảm. Ba là, do nhu cầu lao động ở thành thị cao hơn nông thôn dẫn đến tình trạng dân số ở thành phố tăng lên, nhu cầu về chỗ ở cũng tăng lên vì vậy phát sinh nhu cầu mua bán BĐS, kinh doanh nhà cho thuê

- Tính bền vững đời sống kinh tế: $\mathrm{BĐS} \mathrm{bao} \mathrm{gồm} \mathrm{cả} \mathrm{đất} \mathrm{đai} \mathrm{và} \mathrm{các} \mathrm{công} \mathrm{trình}$ trên đất, đất đai là nguồn tài nguyên do thiên nhiên ban tặng, là tư liệu sản xuất đặc biệt mà không có tài sản nào có thể thay thế được. Nó được tham gia vào quá trình tái sản xuất xã hội nhưng dù đem sử dụng cho mục đích nào đi nữa thì nó cũng vẫn mang lại lợi ích cho chủ sỡ hữu nên mang tính bền vững. Hơn nữa, đất đai được sử dụng để hưởng quyền sở hữu đất đai và hưởng các lợi ích do đất đai mang lại và thời gian sử dụng lại vô hạn làm cho ý nghĩa của đất đai, BĐS được nhân đôi. Điều này thể hiện đời sống kinh tế bền vững

\subsubsection{Khái niệm về môi giới bất động sản}

Trước tiên, có thể định nghĩa môi giới là hoạt động của người thứ ba với mục đích tạo sự thông cảm, thấu hiểu về các vấn đề liên quan giữa các bên với nhau, hoặc là việc giải quyết những công việc nào đó liên quan giữa hai bên - người môi giới lúc này đóng vai trò là cầu nối. Ngoài ra việc môi giới có thể được xác định như là công việc tạo thu nhập thông qua các thương vụ giữa các bên với nhau. Vì vậy môi giới là công việc với mục đích tạo thu nhập mà đối tượng của nó là các thương vụ được thực hiện giữa hai bên. chúng ta xem xét khái niệm về môi giới nói chung. Nói cách khác, môi 


\section{DANH MỤC TÀI LIỆ THAM KHẢO}

\section{Văn bản pháp luật}

1. Hiến pháp 2013 (số: không số) ngày 28/11/2013.

2. Bộ Luật Dân sự 2015 (Luật số 33/2015/QH11) ngày 14/6/2015.

3. Luật Đất đai 1993 (Luật số: không số) ngày 14/07/1993 (hết hiệu lực)

4. Luật Đất đai 2003 (Luật số 13/2003) ngày 26/11/2003 (hết hiệu lực).

5. Luật Đất đai 2013 (Luật số 45/2013/QH13) ngày 29/11/2013.

6. Luật Kinh doanh bất động sản 2006 (Luật số 63/2006/QH11) (hết hiệu lực).

7. Luật Kinh doanh bất động sản 2014 (Luật số 66/2014/QH13) ngày 25/11/2014.

8. Luật nhà ở 2014 (Luật số: 65/2014/QH13) ngày 25/11/2014.

9. Nghị định số 153/2007/NĐ-CP ngày 15/10/2007 của Chính phủ quy định chi tiết hướng dẫn thi hành Luật kinh doanh bất động sản 2006 (hết hiệu lực).

10. Nghị định số 76/2015/NĐ-CP ngày 10/9/2015 của Chính phủ quy định chi tiết thi hành một số điều của Luật Kinh doanh bất động sản 2014.

11. Thông tư 13/2008/TT-BXD hướng dẫn thực hiện một số nội dung của Nghị định số 153/2007/NĐ-CP quy định chi tiết và hướng dẫn thi hành Luật kinh doanh bất động sản 2006 (hết hiệu lực)

12. Thông tư 11/2015/TT-BXD của Bộ Xây dựng ngày 30/12/2015 quy định việc cấp chứng chỉ hành nghề môi giới bất động sản; hướng dẫn việc đào tạo, bồi dưỡng kiến thức hành nghề môi giới bất động sản, điều hành sàn giao dịch bất động sản; việc thành lập và tổ chức hoạt động của sàn giao dịch bất động sản.

13. Quyết định 29/2007QĐ-BXD của Bộ xây dựng quy định về khung đào tạo, bồi dưỡng kiến thức về môi giới bất động sản.

14. Quyết định số 29/2007/QĐ-BXD của Bộ Xây dựng về việc ban hành khung Chương trình đào tạo, bồi dướng kiến thức về môi giới $\mathrm{BĐS,} \mathrm{định} \mathrm{giá} \mathrm{BĐS}$ và quản lý, điều hành sàn giao dịch bất động sản.

\section{Tiếng Việt}

15. Vũ Anh (2004), "Một số vấn đề về pháp luật thị trường bất động sản ở Việt Nam", Tạp chí Nhà nước và pháp luật, 2(190), tr.21-29. 
16. Đinh Văn Ân (2011), Chính sách phát triển thị truoòng bất động sản ở Việt Nam, Nxb Chính trị Quốc Gia, Hà Nội.

17. Phạm Minh Chính, Vương Quân Hoàng (2009), Kinh tế Việt Nam - Thăng trầm và Đột phá, Nxb. Chính trị Quốc gia, Hà Nội.

18. Trần Việt Dũng (2017), "Một số giải pháp phát triển bền vững thị trường bất động sản”, Tạp chí Tài chính, 9(651), tr. 32-33.

19. Phùng Thị Thu Hà (2013), Pháp luật về môi giới bất động sản ở Việt Nam Luận văn thạc sĩ, Trường Đại học quốc gia Hà Nội.

20. Bùi Mạnh Hùng (2013), Môi giới và kinh doanh bất động sản, Nxb. Xây dựng, Hà Nội.

21. Nguyễn Mạnh Hùng (2016), "Thị trường bất động sản Việt Nam thực trạng và giải pháp", Tạp chi Truờng Đại học Nam Cần Tho:

22. Lưu Đức Khải và Hà Huy Ngọc (2009), "Kinh nghiệm thực tiễn dịch vụ môi giới BĐS: Kinh nghiệm quốc tế thực tiễn và định hướng phát triển ở Việt Nam”, Tạp chí Quản lý Kinh tế, (24), tr. 55-60.

23. Phan Nữ Khánh Linh (2008), Pháp luật về môi giới bất động sản ở Việt Nam, TP. Hồ Chí Minh.

24. Doãn Hồng Nhung (2007), “Thị trường bất động sản: Hứa hẹn sự phát triển lành mạnh và đúng hướng”, Tạp chí Xây dụng, (468), tr. 11-13.

25. Doãn Hồng Nhung (2014), “Tạo dựng đẳng cấp thương hiệu môi giới BĐS và một số giải pháp hoàn thiện pháp luật về môi giới BĐS ở Việt Nam", Tạp chíxây dụng, (20), tr. 51-54.

26. Lưu Quốc Thái (2005), "Pháp luật đất đai và vấn đề khung pháp lý cho thị trường bất động sản ở nước ta”, Tạp chí Khoa học pháp lý, 1(26), tr.14-26.

27. Đặng Đức Thành (2009), Kinh doanh bất động sản chuyên đề "môi giới", Nxb. Thanh niên, Hà Nội.

28. Đặng Đức Thành (2010), Kinh doanh bất động sản : thực trạng và giải pháp Việt Nam, Nxb. Thanh niên, Hà Nội.

29. Nguyễn Ngọc Tú (2007), Thống nhất pháp luật về đăng ký bất động sản, Luận văn thạc sĩ, Trường Đại học Luật Hà Nội.

30. Nguyễn Quang Tuyến, Nguyễn Thị Nga (2011), "Pháp luật môi giới bất động sản Việt Nam và kiến nghị hoàn thiện", Tạp chí luật học, (6), tr. 47-52. 
31. U. Wysokiska (2002), “Quan hệ giữa người bán người mua và nhà môi giới”, Tạp chí ghi chép về thị trường bất động sản, (06).

32. Đặng Hùng Võ (2017), “Thị trường bất động sản và dự báo cơ hội đầu tư", Tạp chí Tài chính, 9(650), tr. 63-65.

\section{Tài liệu điện tử}

33. Thông tin pháp luật dân sự, "Khái niệm, đặc điểm, phân loại bất động sản”, https://thongtinphapluatdansu. edu.vn/2008/01/01/3521/, Ngày truy cập $10 / 11 / 2017$.

34. Công ty luật Minh Khuê, "Số liệu bình quân tháng trong giai đoạn 2005 - 2007”, https://luatminhkhue.vn/kien-thuc-luat-dat-dai/chuyen-de--tong-quan-vedich-vu-moi-gioi-bat-dong-san.aspx, Ngày truy cập 10/11/2017.

35. Chứng Khoán Bảo Việt, "10 nguyên nhân khiến thị trường bất động sản yếu kém, bất cập" http://www.bvsc. com.vn/News/2014623/294822/10-nguyen-nhankhien-thi-truong-bat-dong-san-yeu-kem-bat-cap.aspx, Ngày truy cập $10 / 11 / 2017$.

36. Vietnamnet, “Con đường nào cho môi giới bất động sản?”, http://vietnamnet.vn /vn/bat-dong-san/con-duong-nao-cho-moi-gioi-bat-dong-san-290042.html, Ngày truy cập: 10/11/2017.

37. Hải Quan, "Chất lượng môi giới bất động sản Việt Nam còn thấp”, http://www.baohaiquan.vn/Pages/Chat-luong-moi-gioi-BDS-Viet-Namthap-hon-cac-nuoc-trong-khu-vuc.aspx, ngày truy cập: 10/11/2017.

38. Hà Nội Mới cơ quan của thành ủy Đảng cộng sản Việt Nam thành phố Hà nội, “Quy định mới về môi giới bất động sản chưa đủ để dẹp cò”, http://hanoimoi.com.vn/Tin-tuc/Bat-dong-san/825637/quy-dinh-moi-vemoi-gioi-bat-dong-san-chua-du-de-dep-co, ngày truy cập: 10/11/2017.

39. Đặng Hùng Võ, “Toàn cảnh thị trường bất động sản năm 2016 và triển vọng năm 2017”, http://kinhtevadubao.vn/chi-tiet/100-7652-toan-canh-thi-truong-batdong-san-nam-2016-va-trien-vong-nam-2017.html, ngày truy cập: 10/12/2017.

40. Viện nghiên cứu, đào tạo kinh tế - tài chính, "Chuyên đề: Tổng quan về dịch vụ môi giới bất động sản”, nguồn: https://luatminhkhue.vn/kien-thuc-luat-dat- 
dai/chuyen-de--tong-quan-ve-dich-vu-moi-gioi-bat-dong-san.aspx, truy cập: 20/12/2017.

41. Thanh Ngà, Gia Bảo, Đăng Khải, "10 ấn tượng của thị trường bất động sản năm 2017”, http://cafef.vn/10-an-tuong-cua-thi-truong-bat-dong-san-nam-2017mot-nam-nong-sotva-bung-no-20171229184259773.chn, ngày truy cập: 20/12/2017.

42. Tài sản giàu, thu nhập nghèo? Những thành phần cơ bản đảm bảo thu nhập hưu trí cho lực lượng dân số đang già hóa ở Chấu Á, http://www.manulifeam.com.vn /Data/Sites/1/media/Baocaothang/Ta-san-giau-thu-nhap-ngheo-BC-thu-bave-tinh-trang.pdf, ngày truy cập: 23/03/2018.

43. Tổng quan về hoạt động đầu cơ ở nước ta, tailieu.ttbd.gov.vn:8080/ index.php/.../242_7158d4c567d64d3f8c07bce3f287cb43, ngày truy cập: 23/3/2018.

44. Năng lực cạnh tranh của doanh nghiệp bất động sản, http://www.misa.com.vn/tintuc/chi-tiet/newsid/21488/Nang-luc-canh-tranh-cua-doanh-nghiep-batdong-san, ngày truy cập: 23/3/2018.

45. Chuyên đề: Tổng quan về dịch vụ môi giới bất động sản, https://luatminhkhue.vn/tu-van-luat-dat-dai/chuyen-de--tong-quan-ve-dichvu-moi-gioi-bat-dong-san.aspx, ngày truy cập: 23/03/2018. 